\title{
PROGRAM KEMITRAAN MASYARAKAT (PKM) PENATAAN RUANG KAWASAN RESAPAN AIR DI KELURAHAN TOUNSARU KECAMATAN TONDANO SELATAN KABUPATEN MINAHASA
}

\author{
Abdul Rahman Dilapanga, Jeane Mantiri \\ Universitas Negeri Manado \\ abdulrahmandilapanga@unima.ac.id,jeanelitha@unima.ac.id
}

\begin{abstract}
Abstrak
Tujuan dari pengabdian ini adalah; (1) Analisis dalam menginterpretasiskan Implementasi Penataan Daerah Resapan Air di Kelurahan Tounsaru Kecamatan Tondano Selatan; (2) Melakukan sosialisasi mengenai faktor-faktor penghambat dalam Implementasi Penataan Daerah Resapan Air di Kelurahan Tounsaru Kecamatan Tondano Selatan untuk merealisasikan Penataan Daerah Resapan ; (3) Memberikan sosialisasi dan pelatihan kepada masyarakat yang masih minim mengetahui mengenai program, alur dan ketentuan dari Penataan Daerah Resapan Air di Kelurahan Tounsaru Kecamatan Tondano Selatan; (4) Menentukan vegetasi yang tepat untuk ditanam di daerah resapan. Beberapa diantaranya adalah bambu, beringin, bisbul (sejenis kesemek), rambutan, nangka, manggis, dan matoa.

Penelitian ini bertempat di Kelutrahan Tonsaru Kecamatan Tondano Selatan Kabupaten Minahasa, dengan menggunakan metode kombinasi pendekatan Pilot Project dengan pendekatan partisipatif (Participatory Rural Appraisal) dan pemahaman desa secara cepat (Rapid Rural Appricial). Dan menghasilkan bahwa; (1) Pada umumnya Kelurahan suatu daerah lebih cenderung mempertimbangkan faktor kebutuhan ruang dan nilai ekonomis dibandingkan dengan faktor lingkungan; (2) Perlu adanya kajian potensi resapan air tanah dengan modelmodel penentuan resapan air tanah yang sudah ada, yang nantinya dipakai sebagai salah satu dasar dalam penyusunan RTRW suatu daerah; (3) Perlu adanya kriteria-kriteria (model) yang baku untuk menentukan suatu kawasan resapan air tanah; (4) Secara umum kriteriakriteria atau parameter yang dipakai sebagai dasar penentuan kawasan resapan air adalah : kelulusan batuan, curah hujan, tanah penutup, kemiringan lahan dengan bobot dan pengklasifikasian tertentu; (5) Distribusi kelas kesesuaian kawasan resapan air di Kelurahan Tonsaru Kecamatan Tondano Selatan Kabupaten Minahasa terdiri atas kurang sesuai, cukup sesuai, dan tidak sesuai.
\end{abstract}

Kata Kunci: Resapan, Tonsaru, Aliran

\section{PENDAHULUAN}

\section{Analisis Situasi}

Daerah resapan air pada hakikatnya adalah sebuah daerah yang disediakan untuk masuknya air dari permukaan tanah ke dalam zona jenuh air sehingga membentuk suatu aliran air di dalam tanah. Fungsi dari daerah resapan air sendiri adalah untuk menampung debit air hujan yang turun di daerah tersebut. Secara tidak langsung daerah atau kawasan resapan air memegang peran penting sebagai pengendali banjir dan kekeringan di musim kemarau. Dampak yang terjadi bila alih fungsi lahan yang terjadi tak terkendali diantaranya ialah banjir. Banjir terjadi karena tidak adanya tanah yang menampung air hujan. Dampak yang lain yakni kekeringan diwaktu musim kemarau, hal ini terjadi karena air hujan yang turun di musim 


\section{Jurnal ABDIMAS, Vol. 13, No. 1, April 2020 ISSN: 1979-0953 | e-ISSN: 2598-6066}

hujan tidak tertampung di dalam tanah akibat penebangan pohon.

Untuk lebih mengoptimalkan konsep penataan ruang lebih khusus konsep tentang kasawan resapan air, maka Peraturan-Peraturan perundangundangan telah banyak diterbitkan oleh pihak pemerintah, dimana salah satu peraturan Perundang-Undangan yang mengatur penataan ruang adalah UndangUndang No. 26 Tahun 2007 tentang Penataan Ruang.

Undang-Undang No. 26 Tahun 2007 merupakan Undang-Undang pokok yang mengatur tentang pelaksanaan penataan ruang [1]. Kawasan lindung adalah wilayah yang ditetapkan dengan fungsi utama melindungi kelestarian lingkungan hidup yang mencakup sumber daya alam dan sumber daya buatan. Dalam Pasal 17 ayat

(4) "Peruntukan kawasan lindung dan kawasan budi daya meliputi peruntukan ruang untuk kegiatan pelestarian lingkungan, sosial, budaya, ekonomi, pertahanan, dan keamanan". Dalam pasal 26 ayat (1) huruf c yaitu "Rencana pola ruang Wilayah Kabupaten yang meliputi kawasan lindung kabupaten dan kawasan budidaya kabupaten. Dalam Peraturan Pemerintah Republik Indonesia Nomor 26 Tahun 2008 tentang Rencana Tata Ruang Wilayah Nasional Dalam Pasal 56 Ayat (3)

"Kawasan Resapan air ditetapkan dalam kriteria kawasan yang mempunyai kemampuan tinggi untuk meresapkan air hujan sebagai pengontrol tata air permukaan".

"Keputusan Presiden No. 32 Tahun 1990 Tentang Pengelolaan Kawasan Lindung. Dalam pasal 1 angka 5 "Kawasan Resapan air adalah daerah yang mempunyai kemampuan tinggi untuk meresapkan air hujan sehingga merupakan tempat pengisian air bumi (akifer) yang berguna sebagai sumber air." Dalam pasal 11 "Perlindungan terhadap kawasan resapan air dilakukan untuk memberikan ruang yang cukup bagi peresapan air hujan pada daerah tertentu untuk keperluan penyediaan kebutuhan air tanah dan penenggulangan banjir, baik untuk kawasan bawahannya maupun kawasan yang bersangkutan." "Pasal 12 Kriteria kawasan resapan air adalah curah hujan yang tinggi, struktur tanah meresapkan air dan bentuk geomorfologi yang mampu meresapkan air hujan secara besar-besaran." [2].

Selanjutnya, Peraturan Daerah Provinsi Sulawesi Utara Nomor 1 Tahun 2014 tentang Rencana Tata Ruang Wilayah Provinsi Sulawesi utara Tahun 2014 - 2034 dalam pasal 45 ayat (1) yaitu Rencana Pola Ruang wilayah Propinsi, terdiri dari a. kawasan lindung dan b.kawasan budidaya dan dalam pasal 46 ayat (1) huruf a dan b yang berisi : a. Kawasan hutan lindung, b. Kawasan yang memberikan perlindungan terhadap kawasan dibawahnya berupa kawasan 
resapan air. Dalam Peraturan Daerah Kabupaten Minahasa Nomor 1 Tahun 2014 tentang RTRW Kabupaten Minahasa Tahun 2014-2034 dalam pasal 19 huruf a: Kawasan yang memberikan perlindungan terhadap kawasan dibawahnya dan pada pasal 20 ayat (1) kawasan yang memberikan perlindungan terhadap kawasan dibawahnya termasuk kawasan resapan air. Dan Pasal 20 ayat (4) "Kawasan resapan air adalah kawasan yang memiliki kemiringan lahan diatas 300 yang terbesar diseluruh wilayah Kabupaten [3].

Menurut Observasi awal yang di lakukan di Kelurahan Tonsaru Kecamatan Tondano Selatan, terdapat permasalahan dengan daerah resapan air yaitu, disetiap hujan turun air naik ke permukaan jalan karena daerah resapan air kurang berfungsi secara baik. Hal disebabkan karena tertutupnya ruang kawasan resapan air, serta masyarakat yang membuang sampah tidak pada tempatnya.

Disamping itu pula penebangan pohon/kayu juga menjadi penyebab lainnya karena pohon juga bisa membantu meresap air dari permukaan ke dalam tanah, pengalihan fungsi lahan dari persawahan menjadi daerah permukiman. Penyebab lainnya juga karena ketambahan jumlah penduduk yang memerlukan tempat tinggal/permukiman sedangkan wilayah tersebut tidak bisa didirikan bangunan (kawasan resapan air) tapi dipaksakan untuk didirikan bangunan. Pemerintah seharusnya mengambil langkah tegas akan hal ini tapi pemerintah hanya diam melihat kawasan resapan air mulai habis karena akan dialihfungsikan menjadi permukiman.

Setelah dilakukan pengukuran di dua lokasi resapan air di Kembuan Timu lokasi resapan yang sebenarnya $\pm 100 \mathrm{M}_{2}$ namun lokasi yang sudah digunakan warga sebagai kawasan resapan air adalah $\pm 30 \mathrm{M}_{2}$ jadi lokasi resapan air yang tersisa $\pm 70 M_{2}$. Dan di Kembuan Amian (Tabu) lokasi resapan yang sebenarnya $\pm 132 \mathrm{M}_{2}$ namun lokasi yang sudah digunakan warga sebagai kawasan resapan air adalah $\pm 32 \mathrm{M}_{2}$ jadi lokasi resapan air yang tersisa $\pm 100 \mathrm{M}_{2}$.Masyarakat yang tinggal di lokasi resapan air belum memiliki Ijin Mendirikan Bangunan (IMB) jadi masyarakat belum memahami benar tentang kawasan yang bisa dijadikan permukiman atau tidak.

Menurut Bupati Minahasa Drs. Jantje W. Sajow, M.Si untuk wilayah yang sudah tidak produktif nantinya akan diubah untuk dijadikan tempat usaha, namun yang masih produktif tidak boleh diganggu. Masalah yang sangat krusial harus dilakukan adalah pembenahan terhadap drainase, sebab beberapa tempat yang dulunya memiliki drainase cukup besar dan dalam sekarang sudah berubah menjadi lebih kecil dan banyak tersumbat sampah. 
Karena pengalihan dari Kawasan Resapan Air menjadi permukiman mengakibatkan banjir di daerah bawah resapan air yaitu daerah banjir seperti Kelurahan Tounsaru, Tataaran Patar, Tataaran I \& 2. Sebenarnya kawasan ini harus ada perhatian khusus dari pemerintah dan mengembalikan fungsi Kawasan Resapan Air yang telah di rubah fungsinya. Seperti pada gambar 1.1 .

Menurut Peta Rencana Pola Ruang RTH Bagian Wilayah Perkotaan Tondano Kabupaten Minahasa, menunjuhkan bahwa Kelurahan Tonsaru Kecamatan Tondano Selatan merupakan daerah kawasan resapan air namun sudah dialihkan fungsi menjadi permukiman masyarakat.

\section{Permasalahan Mitra}

Berdasarkan Analisis Situasi di atas, maka permasalahan Mitra ada pada masyarakat yang ada di Kelurahan Tounsaru Kecamatan Tondano Selatan adalah:

1. Terdapat permasalah terhadap daerah resapan air di Kelurahan Tonsaru Kecamatan Tondano Selatan.

2. Kurangnya pengetahuan masyarakat tentang ketentuan, syarat maupun pedoman untuk Penataan Ruang Kawasan Resapan Air.
3. Drainase besar dan yang sekarang sudah berubah menjadi lebih kecil dan banyak tersumbat sampah.

\section{SOLUSI DAN TARGET LUARAN}

Luaran dan Target Capaian

Rencana Luaran

a. Sosialisai kegiatan Penataan Ruang Kawasan Resapan Air

b. Sosialisasi mengenai hambatan hambatan dalam program Penataan Ruang Kawasan Resapan Air

c. Lahan yang sudah bersih dan sudah ditanami tanaman penyerap air

\section{Solusi yang ditawarkan untuk mengatasi permasalahan yang} dihadapi

1. Analisis dalam menginterpretasiskan Implementasi Penataan Daerah Resapan Air di Kelurahan Tounsaru Kecamatan Tondano Selatan.

2. Melakukan sosialisasi mengenai faktor-faktor penghambat dalam Implementasi Penataan Daerah Resapan Air di Kelurahan Tounsaru Kecamatan Tondano Selatan untuk merealisasikan Penataan Daerah Resapan . 
3. Memberikan sosialisasi dan pelatihan kepada masyarakat yangmasihminim mengetahui mengenai program, alur dan ketentuan dari Penataan Daerah Resapan Air di Kelurahan Tounsaru Kecamatan Tondano Selatan.

4. Menentukan vegetasi yang tepat untuk ditanam di daerah resapan. Beberapa diantaranya adalah bambu, beringin, bisbul (sejenis kesemek), rambutan, nangka, manggis, dan matoa.

5. Memperbaiki kondisi tanah agar mudah menyerap air

\section{METODE PELAKSANAAN}

1. Metode Pelaksanaan kegiatan Metode pendekatan yang akan

diterapkan dalam pelaksanaan kegiatan penerapan produk teknologi yang dideseminasikan kepada masyarakat ini yaitu merupakan kombinasi pendekatan Pilot Project dengan pendekatan partisipatif (Participatory Rural Appraisal) dan pemahaman desa secara cepat (Rapid Rural Appricial). Pendekatan pemahaman desa secara partisipatif atau PRA dan RRA selama ini dianggap sebagai salah satu pendekatan atau metode pembangunan di pedesaan yang paling sesuai dimana permasalahan secara mendasar dapat dipahami dan terungkap serta proses perencanaan dalam mengatasi masalah juga merupakan buah pemikiran bersama dengan masyarakat itu sendiri. Kegiatan ini diharapkan dapat memecahkan masalah utama yang dihadapi oleh kelompok yaitu rendah dan dan minim kemampuan dalam Penataan Daerah Resapan Air di Kelurahan Tounsaru Kecamatan Tondano Selatan.

\section{Prosedur Kerja Persiapan.}

Tahapan kegiatan yang akan dilakukan oleh tim pelaksana penerapan produk teknologi yang akan didesiminasi kepada masyarakatv diawali dengan pembahasan program dan langkah-langkah kerja tim mulai dari pembagian tugas dan tanggungjawab berdasarkan kompetensi masing-masing anggota tim sampai dengan persiapan administrasi dan perangkat pendukung. Selanjutnya secara bersama tim kerja menyusun draft instrumen yang akan digunakan sebagai acuan dalam menjaring informasi atau data akurat tentang permasalahan mendasar mitra. Dengan demikian instrumen yang disusun mencakup identifikasi atau penjaringan informasi permasalahan mendasar yang harus dipahami secara bersama sebelum mengawali penerapan produk teknologi yang didesiminasi ke masyarakat. Langkah persiapan yang lainnya adalah pemantapan pemahaman atau penyamaan 
persepsi tentang program yang akan dijalankan oleh tim itu sendiri serta persiapan bahan dan alat yang akan digunakan dalam pelaksanaan kegiatan ini.

Prosedur persiapan dan pelaksanaan kegiatan untuk mewujudkan solusi yang ditawarkan dilaksanakan secara bersama anggota tim pengusul dengan mitra dan dijabarkan sebagai berikut:

A. Tahap Persiapan, terdiri dari beberapa kegiatan:

1. Pembentukan tim yang dilanjutkan dengan rapat untuk menentukan tema, lokasi dan mitra kerjasama.

2. Koordinasi dengan pihak mitra untuk mendiskusikan permasalahan yang utama yang dihadapi mitra dan solusi yang ditawarkan untuk menyelesaikan permasalahan tersebut serta memilih pendekatan untuk merealisasikan solusi yang telah disepakati.

3. Survey pendahuluan ke lokasi yang menjadi target pelaksanaan kegiatan.

4. Rapat persiapan tim untuk membuat usulan/proposal pengabdian masyarakat

\section{Pelaksanaan Kegiatan}

a. Sosialisasi.
Langkah awal yang akan dilakukan dalam proses pelaksanaan kegiatan adalah sosialisasi. Kegiatan sosialisasi merupakan salah satu tahapan penting dalam menyampaikan hal-hal yang berkaitan dengan program dan kegiatan penerapan produk teknologi yang didesiminasikan ke masyarakat. Kegiatan sosialisasi lebih ditekankan kepada pemberian pemahaman dan pengertian kepada masyarakat tentang pentingnya kegiatan yang akan dilaksanakan ini berkaitan dengan upaya perbaikan proses produksi aneka produk pascapanen tanaman perkebunan maupun pertanian tanaman pangan terutama dalam kaitan dengan aspek pengeringan.

\section{b. Proses Pembelajaran/Pelatihan}

Setelah sosialisasi, pelaksanaan kegiatan akan ditindaklanjuti dengan kegiatan proses pembelajaran dan kegiatan praktek atau implementasi ilmu pengetahuan dan teknologi terhadap warga belajar sesuai dengan apa yang sudah direncanakan dan disepakati bersama dengan kedua mitra. Materi yang akan diberikan meliputi teori dan praktik. Metode pembelajaran adalah menggunakan metode ceramah, diskusi, demonstrasi pengenalan cara kerja dan fungsi alat pengering tersebut, serta metode simulasi dengan audiovisual. Berbagai alat bantu ajar yang akan digunakan untuk mempercepat proses 
pembelajaran berupa slide, dan video.

Bertolak dari permasalahan utama yang

akan diatasi secara bersama maka secara

umum materi (teori) yang akan diberikan

meliputi hal-hal sebagai berikut.

\section{c. Tahap Pelaksanaan Kegiatan, terdiri}

\section{dari beberapa kegiatan:}

1. Penyampaian undangan untuk meminta kesediaan Lurah, beberapa aparat pemerintah, dan beberapa tokoh masyarakat untuk datang berpartisipasi dalam kegiatan penyuluhan yang akan dilaksanakan.

2. Menyiapkan tempat pertemuan yang dilengkapi dengan fasilitas yang cukup untuk menampung peserta penyuluhan yang hadir.

3. Menyiapkan peralatan berupa LCD dan wireless yang akan digunakan dalam pelaksanakan kegiatan.

4. Menyiapkan bahan materi dan peralatan sederhana untuk kegiatan penyuluhan mekanisme pengendalian pemanfaatan ruang wilayah kota di Kelurahan Tounsaru Kecamatan Tondano Selatan Kabupaten Minahasa

5. Pelaksanaan kegiatan penyuluhan, secara rinci dijelaskan sebagai berikut:

a. Kegiatan penyuluhan kepada aparat pemerintah di lingkup wilayah

$\begin{array}{lr}\text { Kelurahan } & \text { Tonsaru } \\ \text { mengenai } & \text { berbagai } \\ \text { regulasi } & \text { menyangkut } \\ \text { pembinaan } & \text { kepada } \\ \text { masyarakat } & \text { dalam }\end{array}$

penataan ruang sehingga masyarakat dapat berperan aktif di wilayah kerjanya. Sesi ini disampaikan secara umum oleh

b. Kegiatanpenyuluhan kepada aparat pemerintah di lingkup wilayah Kecamatan Biringkanaya mengenai regulasi dan substansi pengendalian pemanfaatan ruang, dibawakan oleh tim dosen sebagai berikut:

i. Materi tentang peraturan zonasi, ii. Materi tentang perizinan, iii. Materi tentang pemberian insentif dan disinsentif.

c. Materi tentang pengenaan sanksi

d. Kegiatan penyuluhan kepada aparat pemerintah di lingkup wilayah Kecamatan Biringkanaya mengenai mekanisme 
pengendalian

pemanfaatan ruang.

e. Dibuka sesi tanya jawab untuk peserta penyuluhan untuk lebih memperdalam pemahaman terkait materi yang disampaikan

\section{Proses Evaluasi dan Pemantapan}

\section{Program Kerja}

Tahapan ini lebih merupakan tindakan yang didasarkan pada hasil evaluasi pada setiap tahapan program berjalan, yaitu apabila berdasarkan hasil evaluasi setiap program berjalan belum diperoleh hasil yang optimal atau sesuai harapan maka akan ditindak lanjuti dengan proses pemantapan program sesuai bagian yang dirasa masih kurang atau belum mencapai tujuan/sasaran.

\section{HASIL DAN PEMBAHASAN}

\section{Gambaran Iptek}

Konsep Penatagunaan Lahan

Menurut soemarto, dalam rangka penatagunaan lahan, beberapa pengertian yang perlu diberikan sebagai batasan adalah sebagai berikut:

1. Tanah (Lahan) adalah ruang daratan, meliputi permukaan bumi yang dalam penggunaannya termasuk tubuh bumi dan air serta ruang yang ada di atasnya, sekedar diperlukan untuk kepentingan yang langsung berhubungan dengan penggunaan lahan itu.

2. Tataguna lahan adalah struktur dan pola pemanfaatan lahan, baik yang direncanakan maupun maupun tidak, yang meliputi persediaan, peruntukan dan penggunaan lahan serta pemeliharaannya.

3. Penatagunaan lahan adalah pengelolaan tataguna lahan berupa penyesuaian penggunaan lahan untuk mewujudkan pemanfaatan lahan yang sesuai dengan rencana tata ruang wilayah, meliputi kegiatan perencanaan penatagunaan lahan, pengaturan pemanfaatan lahan dan pengendalian pemanfaatan lahan dengan memperhatikan perkembangan teknologi.

4. Persediaan tanah (lahan) adalah fakta hasil penilaian potensi fisik tanah di seluruh atau di sebagian wilayah negara, sehubungan dengan kemungkinan peruntukan dan penggunaannya untuk memenuhi kebutuhan pembangunan.

5. Peruntukan tanah (lahan) adalah keputusan terhadap suatu bidang tanah atau unit wilayah tertentu guna dimanfaatkan bagi tujuan penggunaan tertentu. 
6. Penggunaan lahan adalah wujud kegiatan atau usaha
memanfaatkan lahan untuk
memenuhi kebutuhan tertentu.

Perubahan Penggunaan Lahan Perubahan penggunaan lahan

diartikan sebagai perubahan suatu jenis penggunaan lahan ke penggunaan lainnya. Konversi lahan dapat bersifat parmanen dan juga dapat bersifat sementara. Jika Lahan pertanian beririgasi teknis berubah menjadi perumahan atau industri maka alih fungsi lahan ini bersifat parmanen

[4]. Menurut Iwan Nugroho dkk, 2012, alih fungsi lahan adalah sebuah mekanisme yang mempertemukan permintaan dan penawaran terhadap lahan dan menghasilkan lahan baru dengan karakteristik sistem produksi yang berbeda. Fenomena alih fungsi lahan adalah bagian dari perjalanan tranformasi struktur ekonomi nasional.

Resapan Air

Secara umum proses resapan air tanah ini terjadi melalui 2 proses berurutan, yaitu infiltrasi (pergerakan air dari atas ke dalam permukaan tanah) dan perkolasi yaitu gerakan air ke bawah dari zona tidak jenuh ke dalam zona jenuh air. Daya infiltrasi adalah laju infiltrasi maksimum yang mungkin, yang ditentukan oleh kondisi permukaan tanah. Daya perkolasi adalah laju perkolasi maksimum yang mungkin, yang besarnya ditentukan oleh kondisi tanah di zona tidak jenuh. Laju infiltrasi akan sama dengan intensitas hujan jika laju infiltrasi masih lebih kecil dari daya infiltrasinya. Perkolasi tidak akan terjadi jika porositas dalam zona tidak jenuh belum mengandung air secara maksimum.

Proses infiltrasi berperan penting dalam pengisian kembali lengas tanah dan air tanah. Pengisian kembali lengas tanah sama dengan selisih antara infiltrasi dan perkolasi (jika ada). Pengisian kembali air tanah sama dengan perkolasi dikurangi kenaikan kapiler (jika ada). Resapan air tanah akan menentukan besarnya aliran dasar yang merupakan debit minimum sungai di musim kemarau.

Faktor-faktor yang mempengaruhi daya infiltrasi air adalah (Soemarto):

a. Dalamnya genangan di permukaan tanah, semakin tinggi genangan maka tekanan air untuk meresap ke dalam tanah semakin besar pula.

b. Kadar air dalam tanah, semakin kering tanah infiltrasi semakin besar.

c. Pemampatan tanah, akan memperkecil porositas, pemampatan dapat terjadi karena pukulan butirbutir hujan, penyumbatan pori oleh butir halus, karena 
injakan manusia, binatang dan lain sebagainya.

d. Tumbuh-tumbuhan, jika tertutup oleh tumbuhan akan semakin besar.

e. Struktur tanah, yaitu ada rekahan daya infiltrasi akan memperbesar.

f. Kemiringan lahan dan temperatur air (mempengaruhi kekentalan).

\section{Kawasan Resapan Air}

Kawasan resapan air adalah kawasan yang mempunyai kemampuan tinggi untuk meresapkan air hujan, sehingga merupakan tempat pengisian air bumi (aquifer) yang berguna sebagai sumber air (Peraturan Daerah Kota Manado no 1 Tahun 2014). Menurut Wibowo, Kawasan resapan air adalah daerah tempat meresapnya air hujan ke dalam tanah yang selanjutnya menjadi air tanah. Menurut Peraturan Menteri Pekerjaan Umum No 02 Tahun 2013, tentang Pedoman Penyusunan Rencana Pengelolaan Sumber Daya Air [5].

Daerah resapan air adalah daerah tempat meresapnya air hujan ke dalam tanah yang selanjutnya menjadi air tanah. Kenyataannya semua daratan di muka bumi dapat meresapkan air hujan. Dalam penelitian ini pengertian daerah resapan air ditekankan dalam kaitannya dengan aliran air tanah secara regional. Daerah resapan regional berarti daerah tersebut meresapkan air hujan dan akan mensuplai air tanah ke seluruh cekungan, tidak hanya mensuplai secara lokal dimana air tersebut meresap [6]

Untuk menentukan daerah resapan air sebaiknya dibuat panduan yang sederhana dengan kriteria-kriteria yang mudah dipahami serta dapat diolah atau dilaksanakan dengan manual maupun dengan komputer (dengan teknologi SIG). Tujuan utama dari penentuan daerah resapan air ini adalah agar aliran dasar dalam tanah dapat optimal, tingkat peresapan ini tergantung pada curah hujan, tipe tanah dan batuan, kemiringan tanah, tipe penggunaan lahan dan vegetasi.

Untuk keperluan praktis aspekaspek yang harus diperhatikan dalam menentukan daerah resapan air adalah [6]

1. Kondisi hidrogeologi yang serasi, meliputi : arah aliran air tanah, adanya lapisan pembawa air, kondisi tanah penutup, curah hujan.

2. Kondisi morfologi/ medan/ topografi, semakin tinggi dan datar lahan semakin baik sebagai daerah resapan air. 
3. Tataguna lahan, lahan yang tertutup tumbuhan lebih baik.

Menurut Freeze \& Cherry. menentukan zona resapan dan pelepasan air perlu diperhatikan [6]:

1. Aliran air permukaan dan air tanah.

2. Iklim, terutama curah hujan.

3. Karakteristik hidrogeologi.

4. Topografi, daerah resapan air umumnya bertopografi tinggi dengan kemiringan lahan relatif besar karena tinggi muka air tanah relatif dalam akibat drainase ke bawah, sedangkan daerah rendah muka air tanah menjadi dangkal dan pelepasan air tanah menjadi dominan.

Secara umum kawasan resapan mempunyai ciri-ciri sebagai berikut:

1. Mempunyai arah umum aliran air tanah secara vertikal

2. Air meresap ke dalam tanah sampai muka air tanah

3. Kedudukan muka preatik relatif dalam

4. Kedudukan muka preatik lebih dalam dari muka pisometrik pada kondisi alamiah

5. Daerah singkapan batuan lolos air tidak jenuh air
6. Daerah perbukitan atau pegunungan

7. Kandungan kimia air tanah relative rendah

8. Umur air tanah relatif muda Sedangkan ciri-ciri khusus dari kawasan resapan air adalah [6] :

1. Daerah tubuh dan puncak kerucut gunung api

2. Daerah karst yang mempunyai retakan dan lubang pelarutan

3. Daerah singkapan batuan pembentuk akuifer tertekan bagian hulu

Berdasarkan pembahasan di atas maka dapat dikatakan bahwa

parameterparameter yang perlu diperhatikan untuk penentuan daerah resapan air adalah curah hujan, jenis tanah permukaan, batuan penyusun, kemiringan lahan, dan muka air tanah. Masing-masing parameter mempunyai pengaruh terhadap resapan air ke dalam tanah yang dibedakan dengan nilai bobot . Parameter yang mempunyai nilai bobot paling tinggi merupakan parameter yang paling menentukan kemampuan peresapan untuk menambah air tanah secara alamiah pada suatu cekungan air tanah. Sebagai salah satu model pengkelasan dan pemberian skor dari tiap kelas parameter dijelaskan sebagai berikut: 
Tabel 5.1 Nilai Bobot Parameter Resapan

Air

\begin{tabular}{|c|l|c|r|}
\hline No. & Parameter & $\begin{array}{c}\text { Bobot } \\
\text { Nilai }\end{array}$ & \\
\hline 1. & Keterangan \\
2. & Curah Hujan & 4 & Tinggi \\
3. & Tanah Penutup & 3 & Cukup \\
4. & Kemiringan Lereng & 2 & Sedang \\
5. & Muka Air Tanah & 1 & Rendah \\
\hline
\end{tabular}

a. Jenis Batuan Penyusun

Pengkelasannya berdasarkan permeabilitas dimana hal tersebut sangat dipengaruhi oleh tekstur dan struktur dari tiap jenis batuan. Semakin besar permeabilitas \& koefisien resapan semakin besar skornya

Tabel 5.2 Kelas dan Skor

Kelulusan Batuan

\begin{tabular}{|c|c|c|c|c|}
\hline No & $\begin{array}{l}\text { Permeabili- } \\
\text { tas(m/hari) }\end{array}$ & $\begin{array}{l}\text { Contoh } \\
\text { Batuan }\end{array}$ & Skor & Ket \\
\hline 1 & $>10^{3}$ & Endapan Aluvial & 5 & sgt Ting \\
\hline 2 & $10^{1}-10^{3}$ & $\begin{array}{l}\text { Endapan Kuarter } \\
\text { muda }\end{array}$ & 4 & Tinggi \\
\hline 3 & $10^{-2}-10^{1}$ & $\begin{array}{l}\text { Endapan Kuarter } \\
\text { tua }\end{array}$ & 3 & Cukup \\
\hline 4 & $10^{-4}-10^{-2}$ & Endapan Tersier & 2 & Sedang \\
\hline 5 & $<10^{-4}$ & Batuan Intrusi & 1 & Rendah \\
\hline
\end{tabular}

Sumber : Direktorat Tata Lingkungan

Geologi dan Kawasan Pertambangan, 2004

b. Curah Hujan

Dari segi daya dukung lingkungan, dengan curah hujan yang sama resapan air akan semakin besar jika hujan terjadi dalam waktu yang panjang. Sehubungan dengan hal tersebut dikembangkan faktor hujan infiltrasi yang dihitung :

$\mathrm{RD}=0,01 . \mathrm{P} . \mathrm{Hh}$
Dimana :

$\mathrm{RD}=$ faktor hujan infiltrasi

$\mathrm{P}=$ curah hujan tahunan

$\mathrm{Hh}=$ jumlah hari hujan tiap tahun Semakin tinggi dan lama curah

hujan, semakin besar skornya karena pada dasarnya semakin tinggi dan lama curah hujan semakin besar air yang dapat meresap ke dalam tanah.

Tabel 5.3 Kelas dan skor data curah hujan

\begin{tabular}{|c|l|l|c|c|}
\hline No. & $\begin{array}{l}\text { Curah } \\
\text { Hujan } \\
(\mathrm{mm} / \text { th })\end{array}$ & $\begin{array}{l}\text { Faktor } \\
\text { Hujan } \\
\left.\text { Infiltrasi }{ }^{*}\right)\end{array}$ & Skor & Ktr \\
\hline 1 & $<1.500$ & $<2.775$ & 1 & Rendah \\
2 & $1.500-2.000$ & $2.775-3.700$ & 2 & Sedang \\
3 & $2.000-2.500$ & $3.700-4.625$ & 3 & Cukup \\
4 & $2.500-3.000$ & $4.625-5.550$ & 4 & Tinggi \\
5 & $>3.000$ & $>5.550$ & 5 & Sgt Ting \\
\hline
\end{tabular}

Sumber : Faktor hujan infiltrasi dihitung berdasarkan rata-rata hari hujan di Cekungan Bandung 185 hari/ th.

c. Jenis Tanah Permukaan

Karakteristik tanah yang harus diperhatikan adalah permeabilitas dan nilai faktor infiltrasi.

\section{d. Kemiringan Lahan}

Merupakan variabel yang sangat berpengaruh terhadap proses resapan air dan penentuan Kawasan

Tabel 5.4 Kelas dan skor tiap jenis tanah

\begin{tabular}{|c|c|c|c|c|}
\hline No & \begin{tabular}{|l|} 
Permeabilitas \\
$\left(10^{-5} \mathrm{~m} / \mathrm{dt}\right)$
\end{tabular} & \begin{tabular}{|l|} 
Contoh \\
Batuan
\end{tabular} & Skor & Ktr \\
\hline $\begin{array}{l}1 \\
2\end{array}$ & $\begin{array}{l}\text { lambat }(<2) \\
\text { agak lambat }\end{array}$ & $\begin{array}{l}\text { Kerikil } \\
\text { Pasir }\end{array}$ & $\begin{array}{l}1 \\
2\end{array}$ & $\begin{array}{l}\text { Rendah } \\
\text { Sedang }\end{array}$ \\
\hline 3 & $\begin{array}{l}(2-7) \\
\text { sedang - cepat } \\
(7-15)\end{array}$ & $\begin{array}{l}\text { Kerikil } \\
\text { Lempung } \\
\text { Pasiran }\end{array}$ & 3 & Cukup \\
\hline 4 & $\begin{array}{l}\text { agak cepat } \\
(15-30)\end{array}$ & $\begin{array}{l}\text { Lanau } \\
\text { Lempungan }\end{array}$ & 4 & Tinggi \\
\hline 5 & cepat $(>30)$ & Lempung & 5 & Sgt Ting \\
\hline
\end{tabular}


Sumber : (dengan modifikasi), dengan pengolahan [7]

Konservasi. Tetapi pengaruhnya berbeda terhadap 2 kepentingan tersebut. Untuk kepentingan resapan air semakin besar kemiringan semakin kecil jumlah air yang meresap tetapi akan semakin penting atau perlu untuk dikonservasi. Dalam penelitian ini penskorannya lebih ditekankan pada kepentingan resapan air daripada untuk kepentingan konservasi secara umum meskipun biasanya daerah resapan berada di daerah dengan kemiringan yang relatif besar.

\section{e. Kedalaman Muka Air Tanah}

Kedalaman Muka Air Tanah Semakin dalam kedalaman muka air tanah bebas maka potensi air untuk meresapkan air semakin besar dibandingkan dengan daerah yang muka air tanahnya relatif dangkal. Kemudian untuk menentukan tingkat kesesuaian sebagai kawasan resapan air dilakukan dengan menjumlahkan hasil perkalian antara nilai bobot dan skor pada tiap kelas parameter, dengan menggunakan rumus :

$$
\begin{aligned}
& \text { Nilai Total }=\mathrm{Kb}^{*} \mathrm{Kp}+\mathrm{Pb}^{*} \mathrm{Pp} \\
& +\mathrm{Sb}^{*} \mathrm{Sp}+\mathrm{Lb}^{*} \mathrm{Lp}+\mathrm{Mb}^{*} \mathrm{Mp}
\end{aligned}
$$

Keterangan :

$\mathrm{K}=$ Kelulusan batuan

$\mathrm{P}=$ Curah hujan rata-rata tahunan
$\mathrm{S}=$ Tanah penutup

$\mathrm{L}=$ Kemiringan lereng

$\mathrm{M}=$ Muka air tanah bebas

$\mathrm{b}=$ Nilai bobot

$\mathrm{p}=$ Skor klas parameter

Tabel 5.5 Kelas dan skor kemiringan lahan

\begin{tabular}{|c|l|c|c|c|}
\hline No. & $\begin{array}{l}\text { Kemiringan } \\
\text { Lahan (\%) }\end{array}$ & $\begin{array}{c}\text { Koefisien } \\
\text { Infiltrasi }\end{array}$ & Skor & Ket \\
\hline 1 & $<8$ & $>0,95$ & 5 & Sgt Tinggi \\
2 & $15-$ Aug & 0,8 & 4 & Tinggi \\
3 & $15-25$ & 0,7 & 3 & Cukup \\
4 & $25-45$ & 0,5 & 2 & Sedang \\
5 & $>45$ & 0,2 & 1 & Rendah \\
\hline
\end{tabular}

Sumber : Chow, 1964 dalam Dinas Pertambangan Dati I Jabar, 1997: dengan pengolahan

Beradasarkan rumus tersebut maka akan diperoleh nilai total dari setiap tempat dalam suatu cekungan. Semakin besar nilai totalnya maka semakin besar potensinya untuk meresapkan air ke dalam tanah dengan kata lain semakin sesuai sebagai daerah resapan air. Untuk mengklasifikasinya (membuat zonasi tingkat kesesuaian sebagai daerah resapan) perlu dibuat kelas-kelas berdasarkan nilai total yang ada di seluruh daerah penelitian.

Untuk proses analisis dengan menggunakan teknologi Sistem Informasi Geografi (SIG) maka semua parameter yang dipakai untuk menentukan daerah resapan air dibuat dalam bentuk petapeta. Selain itu dibuat tabel-tabel untuk menjelaskan peta-peta tersebut. Dalam sistem informasi geografi kesemuanya itu 
dibangun dalam suatu database sehingga akan sangat mudah untuk memanipulasi, mengupdate dan menganalisis

Tabel 5.6 Kelas dan skor

kedalaman muka air tanah

\begin{tabular}{|c|l|c|c|}
\hline No. & $\begin{array}{l}\text { Kedalam muka } \\
\text { air tanah }(\mathrm{m})\end{array}$ & Skor & Keterangan \\
\hline 1 & $>30$ & 5 & Sangat Tingg \\
2 & $20-30$ & 4 & Tinggi \\
3 & $10-20$ & 3 & Cukup \\
4 & $5-10$ & 2 & Sedang \\
5 & $<5$ & 1 & Rendah \\
\hline
\end{tabular}

Sumber : Direktorat Tata Lingkungan

Geologi dan Kawasan Pertambangan, 2004 [8]

\subsubsection{Hidrologi air tanah}

Hidrologi air tanah atau sering disebut geohidrologi adalah pengetahuan terjadinya distribusi dan gerakan air di bawah permukaan tanah. Sedangkan air tanah adalah air yang menempati rongga (pori) dalam lapisan tanah, batuan atau formasi geologi yang ada di bawah tanah. Air tanah merupakan sumberdaya yang sangat penting dalam penyediaann air di Indonesia. Penggunaan air tanah sangat luas dan memenuhi sekitar 60\% dari kebutuhan penduduk akan air baik untuk irigasi, industri, air minum, MCK, dll. Beberapa pengetahuan yang sangat berkaitan dengan air tanah adalah geologi, hidrologi, meteorologi, mekanika fluida dan ilmu tanah. Kesemua ilmu memberikan kontribusi yang penting dalam pengkajian potensi air tanah suatu daerah.

\section{KESIMPULAN DAN SARAN}

\subsection{Kesimpulan}

a. Pada umumnya Kelurahan suatu daerah lebih cenderung mempertimbangkan faktor kebutuhan ruang dan nilai ekonomis dibandingkan dengan faktor lingkungan.

b. Perlu adanya kajian potensi resapan air tanah dengan modelmodel penentuan resapan air tanah yang sudah ada, yang nantinya dipakai sebagai salah satu dasar dalam penyusunan RTRW suatu daerah.

c. Perlu adanya kriteria-kriteria (model) yang baku untuk menentukan suatu kawasan resapan air tanah.

d. Secara umum kriteria-kriteria atau parameter yang dipakai sebagai dasar penentuan kawasan resapan air adalah : kelulusan batuan, curah hujan, tanah penutup, kemiringan lahan dengan bobot dan pengklasifikasian tertentu.

e. Distribusi kelas kesesuaian kawasan resapan air di Kelurahan Tonsaru Kecamatan Tondano Selatan Kabupaten Minahasa terdiri atas kurang 
sesuai, cukup sesuai, dan tidak sesuai.

Saran

Berdasarkan kesimpulan di atas, maka saran yang dapat disampaikan dalam penelitian ini antara lain:

1. Pemeliharaab dari hasil Penataan kembali elemen-elemen penciri kawasan resapan air yang berkaitan dengan kegiatan budi daya terbangun, di antaranya penggunaan lahan, dan kemiringan lereng. Hal ini dimaksudkan untuk memperbaiki fungsi resapan air yang berkurang akibat perkembangan luasan permukiman.

2. Penerapan peraturan zonasi yang telah ditetapkan, dan meningkatkan fungsi monitoring dan evaluasi terhadap pemanfaatan ruang yang berjalan.

\section{REFERENSI}

[1] Undang-undang Nomor 26 Tahun 2007 tentang Penataan Ruang,

[2] Keputusan Presiden No. 32 Tahun 1990 Tentang Pengelolaan Kawasan Lindung,

[3] Peraturan Daerah Kabupaten Minahasa No 1 Tahun 2014 Tentang Rencana Tata Ruang Wilayah Kabupaten Minahasa Tahun 2014-2034

[4] Salama, R.B. dkk. 1993. Distribution of Recharge and Discharge Areas in A First Order Catchment as Interpreted from Watter Level Pattern, Journal of Hydrology v. 143, Elseiver, Amsterdam.

Wibowo.2006. Model Penentuan Kawasan Resapan Air Untuk Perencanaan Tata Ruang Berwawasan Lingkungan, Jurnal Hidrosfir, Vol. 1, No. 1,Hal. 1-7.

[6] Anonim.1995.

KesesuaianLahan Untuk

Kegiatan Perkotaan di Bandung, MBUDP, Pemerintah Daerah Propinsi Jawa Barat.

[7] Supriyo, A. 1992. Penyusunan Model Pengkajian dan Rencana Pengelolaan Daerah Resapan (Makalah pada

Penyusunan Rencana Pengelolaan Daerah Resapan Air di Jawa Tengah, di Semarang).

[8] Direktorat Tata Lingkungan Geologi dan Kawasan Pertambangan, 2004 
